\title{
Diversity of frugivorous flies (Tephritidae e Lonchaeidae) in three municipalities in southern Bahia
}

\author{
Diversidade de moscas frugívoras (Tephritidae e \\ Lonchaeidae) em três municípios da região sul da Bahia \\ Elisângela Alves dos Santos Felix Melo ${ }^{*}$, Olivia Oliveira dos Santos², Rodrigo Barros Rocha1, \\ Pedro Carlos Strikis ${ }^{3}$, Maria Aparecida Leão Bittencourt ${ }^{1}$
}

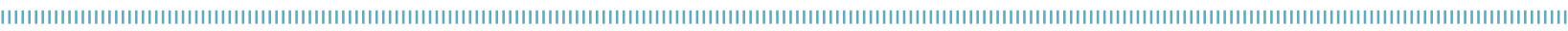

\begin{abstract}
The main goal of this paper was to know the species diversity of frugivorous flies (Tephritidae and Lonchaeidae) in Ilhéus, Uruçuca and Wenceslau Guimarães, municipalities in southern Bahia. In each sampled place five McPhail traps were used containing 5\% corn hydrolyzed protein (Bio Anastrepha $^{\odot}$ ), from July 2011 through December 2012. The captured adults were placed in plastic pots containing $70 \%$ alcohol, until identification, characterized according to diversity indexes of Shannon-Wiener, Margalef and equitability, and categorized according to the total number of captured flies: $2.24 \%$ species of genus Neosilba McAlpine (Lonchaeidae), and 97.76\% species of genus Anastrepha Schiner, with 12 species reported, and Ceratitis capitata. The index fly/trap/day (FTD) oscillated from zero to 1.35 with the highest capture in March and April 2012, coinciding with the fructification period. The frugivorous flies captured were Anastrepha antunesi Lima, A. babiensis Lima, A. consobrina (Loew), A. distincta Greene, A. fraterculus (Wied.), A. grandis (Macquart), A. leptozona Hendel, A. obliqua (Macquart), A. parallela (Wied.), A. serpentina (Wied.), A. sororcula Zucchi, A. zenildae Zucchi, C. capitata (Wied.), Neosilba glaberrima (Wied.) and Neosilba zadolicha McAlpine \& Steyskal. Anastrepha fraterculus was the species with the highest index of frequency, dominance, abundance and constancy. It is the first register of $A$. consobrina in the state of Bahia.
\end{abstract}

KEYWORDS: faunistic analysis; McPhail trap; Tephritoidea.
RESUMO: O principal objetivo deste estudo foi conhecer a diversidade de espécies de moscas frugívoras (Tephritidae e Lonchaeidae) em Ilhéus, Uruçuca e Wenceslau Guimarães, municípios da regiáo sul da Bahia. No período de julho/2011 a dezembro/2012, foram instaladas cinco armadilhas do tipo McPhail em cada local de amostragem, tendo como atrativo alimentar proteína hidrolisada de milho (Bio Anastrepha ${ }^{\odot}$ ) a $5 \%$. Os adultos capturados nas armadilhas, após a triagem, foram acondicionados em potes plásticos com álcool etílico $70 \%$ até a identificação. Cada espécie de Anastrepha foi caracterizada pelos índices de diversidade de Shannon-Wiener, Margalef e equitabilidade e categorizada quanto à sua dominância, abundância, frequência e constância na comunidade. Do total de moscas capturadas, 2,24\% corresponderam a exemplares de Neosilba McAlpine (Lonchaeidae) e 97,76\% a exemplares de moscas-das-frutas, com registro de 12 espécies de Anastrepha e C. capitata. O índice mosca/armadilha/dia (MAD) variou de 0 a 1,35, com maior captura nos meses de março e abril de 2012, coincidindo com o período de frutificação. Registraram-se as ocorrências de Anastrepha antunesi Lima, A. babiensis Lima, A. consobrina (Loew), A. distincta Greene, A. fraterculus (Wied.), A. grandis (Macquart), A. leptozona Hendel, A. obliqua (Macquart), A. parallela (Wied.), A. serpentina (Wied.), A. sororcula Zucchi, A. zenildae Zucchi, Ceratitis capitata (Wied.), Neosilba glaberrima (Wied.) e Neosilba zadolicha McAlpine \& Steyskal. Anastrepha fraterculus atingiu os índices máximos de dominância, frequência, constância e abundância. Registrou-se, pela primeira vez, a espécie $A$. consobrina no estado da Bahia.

PALAVRAS-CHAVE: análise faunística; armadilha McPhail; Tephritoidea.

\footnotetext{
'Universidade Estadual de Santa Cruz (UESC) - Ilhéus (BA), Brazil.

${ }^{2}$ Universidade Estadual do Sudoeste da Bahia (UESB) - Vitória da Conquista (BA), Brazil.

${ }^{3}$ Universidade de São Paulo (USP) - São Paulo (SP), Brazil.

*Corresponding author: elisO1 agro@yahoo.com.br

Received on: 04/04/2014. Accepted on: 09/26/2016
} 


\section{INTRODUCTION}

Frugivorous flies (Diptera: Tephritoidea) cause great economic losses to Brazilian market of fruits and vegetables due to premature fruit drop and to product devaluation for in natura consume and industrialization (AluJA; Mangan, 2008; MinZÃo; UChÔA-Fernandes, 2008).

There are several species of fruit flies infesting fruit orchards in Brazil: Anastrepha Schiner and Ceratitis capitata (Wied.) (Tephritidae), by Neosilba McAlpine, Dasiops Rondani and Lonchaea Fallén (Lonchaeidae) (UchôA-Fernandes et al., 2003; Strikis; Prado, 2005; Zucchi, 2008). Amongst them, fruit flies from family Tephritidae play a major role due to restriction to transit of fresh fruits and quarantine impositions by importing countries (MaLavasi et al., 2000). Studies of faunistic parameters of some fruit flies pest species are fundamental in order to establish strategies of integrated management (BITTENCOURT et al., 2011; SANTOS et al., 2011; SÁ et al., 2012). In northeastern of Brazil, the most frequent fruit flies species are $A$. fraterculus, A. zenildae Zucchi, A. obliqua (Macquart), A. sororcula Zucchi and $A$. serpentina (Wied.), and previous studies carried out in southern Bahia reported $A$. fraterculus as the predominant species (SANtos et al., 2004; Bittencourt et al., 2006a; Feitosa et al., 2008; Santos et al., 2008; Dutra et al., 2009; Azevedo et al., 2010; SANtos et al., 2011; SÁ et al., 2012; AraúJo et al., 2013).

The faunistic indexes (Simpson, Shannon-Wiener, Margalef, abundance, dominance, frequency and constancy) are used to characterize a community, and show that determinant factors of the degree of species abundance are usually linked to ecological components of the habitat and host richness. Some works have shown that, despite many species may be present in some areas, only one or two are considered frequent and dominant (Silveira Neto et al., 1976; Ferrara et al., 2005; Uramoto et al., 2005). Previous knowledge of ecological aspects of species present in orchards and its population dynamics through the year, amongst others faunistic parameters, are important when practicing integrated management of frugivorous flies (Aguiar-Menezes et al., 2008).

So, taking into account the importance of frugivorous flies and the diversity of native fruits in the proximities of remnants of the Atlantic forest in the region, the objectives of this paper were: broaden the knowledge about the diversity of fruit flies in southern Bahia; evaluate the faunistic indexes of ShannonWiener, Margalef, equitability, abundance, constancy, dominance and frequency of Tephritidae flies; and evaluate the population fluctuation using the index fly/trap/day (FTD). areas of Atlantic forest remnants in the municipalities of Ilhéus

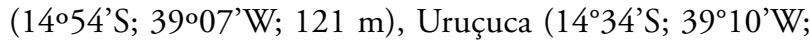

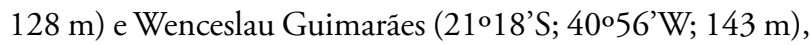
in southern Bahia. In this region the climate is tropical hot humid, with mean annual temperature of $25^{\circ} \mathrm{C}$ and relative humidity of $85 \%$, according to data from Comissão Executiva do Plano da Lavoura Cacaueira (CEPLAC).

In each property, five McPhail traps were fixed in fruit trees approximately $1.5 \mathrm{~m}$ above ground. The traps contained, as food attractant, 5\% corn hydrolyzed protein (Bio Anastreph $\mathrm{a}^{\odot}$ ), and they were placed randomly at the borders of orchards next to the forest. The traps were inspected weekly and captured insects transferred to plastic vials of $50 \mathrm{~mL}$ containing $70 \%$ ethanol, at the same time the traps were washed and attractant renewed. The samples were labeled with the following information: date and place of collect, and strap number. Then, they were taken to the laboratory of Biologic Control of Universidade Estadual de Santa Cruz (UESC), in order to proceed the insect taxonomic identification.

Fruit flies adults sampled were counted and sexed. With the aid of optic stereomicroscope and microscope, females of Anastrepha were identified based on wing pattern (wing stripes), thorax pattern and morphometric characters of aculeo tip (ZuCCHI, 2000a). Males of Anastrepha and specimens of $C$. capitata were counted and discharged. Specimens of Lonchaeidae were identified by Pedro Carlos Strikis, a taxonomist specialized in Lonchaeidae flies.

Each species of Anastrepha were ranked according to the indexes of Shannon-Wiener, Margalef and equitability, and categorized according to its dominance ( $\mathrm{SD}=$ super-dominant, $\mathrm{D}=$ dominant, and $\mathrm{ND}=$ not dominant $)$, abundance (sa = superabundant, $\mathrm{va}=$ very abundant, $\mathrm{c}=$ common, $\mathrm{d}=$ disperse), frequency $(\mathrm{SF}=$ super-frequent, $\mathrm{VF}=$ very frequent, $\mathrm{F}=$ frequent, and $\mathrm{LF}=$ low frequent $)$ and constancy $(\mathrm{W}=$ constant, $Y=$ accessory, $\mathrm{Z}$ = incidental) in the community (Silveira Neto et al., 1976; Uramoto; Walder; ZuCChi, 2005).

Faunistic indexes were calculated using the software ANAFAU, developed at the Department of Entomology and Acarology from Escola Superior de Agronomia "Luiz de Queiroz", of Universidade de São Paulo (USP), Piracicaba, São Paulo. All specimen of frugivorous flies were deposited in the Entomological Collection of the Laboratory of Biological Control at UESC. Population fluctuation of fruit flies is presented by the total number of Tephritidae specimens captured monthly, and population density is expressed in FTD.

\section{MATERIAL AND METHODS}

This work was carried out from July 2011 until December 2012 in three domestic orchards with diverse hosts, located in

\section{RESULTS AND DISCUSSION}

In the three municipalities, 1,783 specimens of fruit flies, 1,743 specimens of Tephritidae ( 1,271 females and 526 males) 
and 40 specimens of Lonchaeidae (38 females and 2 males) were captured.

The genus Anastrepha represented 99.44\% (1,207 females and 521 males) of Tephritidae flies, and C. capitata represented $0.86 \%$ (ten females and five males). So, Anastrepha was considered the predominant species.

In Bahia 31 species of Anastrepha (ZucchI, 2008) were already registered, and among these 12 were registered in this study: Anastrepha antunesi Lima, A. bahiensis Lima, A. consobrina (Loew), A. distincta Greene, A. fraterculus (Wied.), A. grandis (Macquart), A. leptozona Hendel, A. obliqua (Macquart), A. parallela (Wied.), A. serpentina (Wied.), A. sororcula Zucchi, A. zenildae Zucchi and A. consobrina was the last one registered for the first time in Bahia.

Anastrepha fraterculus was predominant in the three municipalities, corresponding to $66.45 \%$ of the captured females reaching the highest indexes of dominance, frequency, constancy and abundance (Tables 1 to 3 ). The highest percentage of capture of $A$. fraterculus is here related to the fact of its poliphagous behavior and the existence of many species of Myrtaceae (its preferred host) in sampled areas. Others studies in this region also showed the dominance of this species (Bittencourt et al., 2006a; Dutra et al., 2009; Santos et al., 2008; SAntos et al., 2011) and in others regions of Brazil (ArAújo et al., 2013; UrAmoto et al., 2004, 2005).

Anastrepha obliqua (11.46\%), also a poliphagous species, was dominant, very abundant, very frequent and constant in Ilhéus and Wenceslau Guimarães. The occurrence of this species in the sampled areas is likely related to the presence of yellow mombin (Spondias mombin L.), hog plum (Spondias purpurea L.) (Anacardiaceae) and star fruit (Averrhoa carambola L., Oxalidaceae). These hosts were close to the places where the traps were located and are considered its preferred hosts (ZuCCHI, 2008).
The presence of fruits of Myrtaceae (guava Psidium guajava L.; Brazilian cherry Eugenia uniflora Berg.; araçá-boi Eugenia stipitata; jambo-red Syzygium malaccense L.) could have favored the frequency of $A$. sorocula and $A$. zenildae in Wenceslau Guimarães, once these hosts fruits ripe in different seasons (ZuCCHI, 2008; BitTEnCOURT et al., 2011; Melo et al., 2012).

Probably the presence of fruits of Helicostylis tomentosa (Moraceae) and guava (Myrtaceae) in Ilhéus propitiated the presence of $A$. bahiensis, since this fruit is the host of this species.

The specimens of $A$. parallela were captured in traps placed inside the Atlantic forest remnants and in areas of cocoa plantation (Theobroma cacao L.) and cupuassu (Theobroma grandiflorum L.), both belonging to family Malvaceae there are records of this species infesting fruits of these family (Zucchi, 2000b, 2008).

The other captured species ( $A$. distincta, $A$. serpentina, A. leptozona, $A$. antunesi, $A$. grandis and $A$. consobrina) showed low frequency in the area, presenting indexes lower than $2 \%$ (Tables 1 to 3 ). It is the first report of $A$. consobrina in Bahia; this species was recorded in the states of Maranhão, Espírito Santo, Rio de Janeiro and São Paulo (Zucchi, 2008).

The results reported in the present work confirm the poliphagous behavior of $A$. fraterculus, $A$. obliqua, $A$. bahiensis, $A$. sororcula and $A$. zenildae, species that have a wide geographic distribution in Brazil and are considered important pests with relevant economic impact (ZuCCHI, 2000a, 2008), except for A. bahiensis.

The biggest diversity of Anastrepha in Ilhéus (ShannonWiener $=1.41$ ), reporting 10 species, is likely related to the greater diversity of available hosts where traps were placed. In Uruçuca, the traps were placed in an orchard close to an Atlantic forest remnant, and probably this fact was responsible

Table 1. Faunistic analysis of Anastrepha species captured in McPhail traps in Ilhéus, July/2011 - December 2012.

\begin{tabular}{|c|c|c|c|c|c|}
\hline Species & Females & Dominance & Abundance & Frequency & Constance \\
\hline A. fraterculus & 329 & SD & sa & SF & W \\
\hline A. obliqua & 74 & D & va & VF & W \\
\hline A. bahiensis & 44 & ND & va & VF & $\mathrm{Y}$ \\
\hline A. parallela & 23 & ND & c & $\mathrm{F}$ & $\mathrm{Y}$ \\
\hline A. serpentina & 21 & ND & c & $\mathrm{F}$ & $\mathrm{Y}$ \\
\hline A. distincta & 17 & ND & c & $\mathrm{F}$ & $\mathrm{Y}$ \\
\hline A. leptozona & 14 & ND & c & $\mathrm{F}$ & $\mathrm{Y}$ \\
\hline A. antunesi & 7 & ND & d & LF & Z \\
\hline A. grandis & 7 & ND & d & LF & Z \\
\hline A. zenildae & 8 & ND & d & LF & $\mathrm{Y}$ \\
\hline
\end{tabular}

Shannon-Wiener index: 1.4149; Margalef index: 1.4288; equitability index: 0.6145; SD: super-dominant; D: dominant; ND: not dominant; sa: super-abundant; va: very abundant; c: common; d: disperse, SF: super-frequent; VF: very frequent; F: frequent; LF: low frequent; W: constant; Y: acessory; Z: incidental. 
for a greater Margalef index (1.8006) and lower number of captured species. In Wenceslau Guimarães the Margalef index was lower (0.9811), due to the dominance of $A$. fraterculus. The high values of Shannon-Wiener and Margalef indexes resulted from the high frequency of $A$. fraterculus, and the relatively high value of equitability showed an equitable distribution of abundance among species in Ilhéus and Uruçuca. The proportional number of specimens of $A$. antunesi, A. bahiensis, A. obliqua, A. parallela and $A$. sororcula decreased the dominance effect of $A$. fraterculus (Tables 1 to 3). The ShannonWiener index reported in this work was similar to that reported for Belmonte, in southern Bahia, that had a value of 1.35 in which nine species of Tephritidae were registered (SANTOS et al., 2011).

The population fluctuation of fruit flies was variable in relation to the studied areas. The greater number female capture occurred in April/2012, probably to the availability and diversity of ripening fruits [yellow sapote (Pouteria caimito Ruiz \& Pav.), araçá-boi, yellow mombin, star fruit, guava e jambo-red]. No specimen of Tephritidae was captured in July/2012, probably because there were no ripening fruits. This fact shows the importance of the presence of ripening fruits to the occurrence of fruit flies in an orchard (ARAúJo et al., 2013; Ronchi-Teles; Silva, 2005).

The FTD index showed little variation during the period of this work. In some months, the value was zero, due to the absence of fruits in the orchards.

In Uruçuca the lowest index of FTD was obtained through the sampling period (0.00 to 0.06 ), with a little rise during the fructification period of yellow mombin (S. mombin) (March/2012).

In Ilhéus the FTD index kept low values with rise in March and April/2012, reaching 1.17. In Wenceslau Guimarães there was a little oscillation in the number of captures females, except for April/2012, when the highest FTD index (1.35) was registered (Fig. 1).

FTD index variation was related to the availability of host fruits (URAмото et al., 2004), with higher values during the period of fruit ripening. In this period, females oviposit in the fruits and the adults emerge in the subsequent months. After the gathering of the fruit for consumption, by the residents of the properties, the fruit flies adults emerge and migrate to other places in search for food and oviposition sites. It makes the FTD index decreases.

Table 2. Faunistic analysis of captured Anastrepha species in McPhail traps in Uruçuca, Bahia, July/2011 - December 2012.

\begin{tabular}{|c|c|c|c|c|c|}
\hline Species & Females & Dominance & Abundance & Frequency & Constance \\
\hline A. fraterculus & 18 & SD & sa & SF & W \\
\hline A. antunesi & 3 & D & va & VF & $\mathrm{Y}$ \\
\hline A. parallela & 3 & $\mathrm{D}$ & va & VF & $\mathrm{Y}$ \\
\hline A. bahiensis & 1 & ND & c & $\mathrm{F}$ & Y \\
\hline A. distincta & 1 & ND & c & $\mathrm{F}$ & $\mathrm{Y}$ \\
\hline A. obliqua & 1 & ND & c & $\mathrm{F}$ & $\mathrm{Y}$ \\
\hline A. serpentina & 1 & ND & c & $\mathrm{F}$ & $\mathrm{Y}$ \\
\hline
\end{tabular}

Shannon-Wiener index: 1.2387; Margalef index: 1.8006; equitability index: 0.6366; SD: super-dominant; D: dominant; ND: not dominant; sa: superabundant; va: very abundant; c: common; SF: super-frequent; VF: very frequent; F: frequent; LF: low frequent; W: constant; Y: acessory; Z: incidental.

Table 3. Faunistic analysis of Anastrepha species captured in McPhail traps in Wenceslau Guimarães Bahia, July/2011-December 2012.

\begin{tabular}{|c|c|c|c|c|c|}
\hline Species & Females & Dominance & Abundance & Frequency & Constance \\
\hline A. fraterculus & 465 & SD & sa & $\mathrm{SF}$ & w \\
\hline A. obliqua & 65 & $D$ & va & VF & $\mathrm{Y}$ \\
\hline A. sororcula & 61 & $\mathrm{D}$ & va & VF & $\mathrm{Y}$ \\
\hline A. zenildae & 18 & ND & c & $\mathrm{F}$ & $\mathrm{Y}$ \\
\hline A. bahiensis & 8 & ND & c & $\mathrm{F}$ & $\mathrm{Y}$ \\
\hline A. distincta & 6 & ND & c & $\mathrm{F}$ & $\mathrm{Y}$ \\
\hline A. consobrina & 5 & ND & c & $\mathrm{F}$ & $\mathrm{Y}$ \\
\hline A. grandis & 2 & ND & $d$ & LF & Z \\
\hline A. leptozona & 5 & ND & c & $\mathrm{F}$ & $Y$ \\
\hline
\end{tabular}

Shannon-Wiener index: 1.2396; Margalef index: 0.981 1; equitability index: 0.4465; SD: super-dominant; D: dominant; ND: not dominant; sa: super-abundant; va: very abundant; c: common; d: disperse; SF: super-frequent; VF: very frequent; F: frequent; LF: low frequent; W: constant; Y: acessory; Z: incidental. 


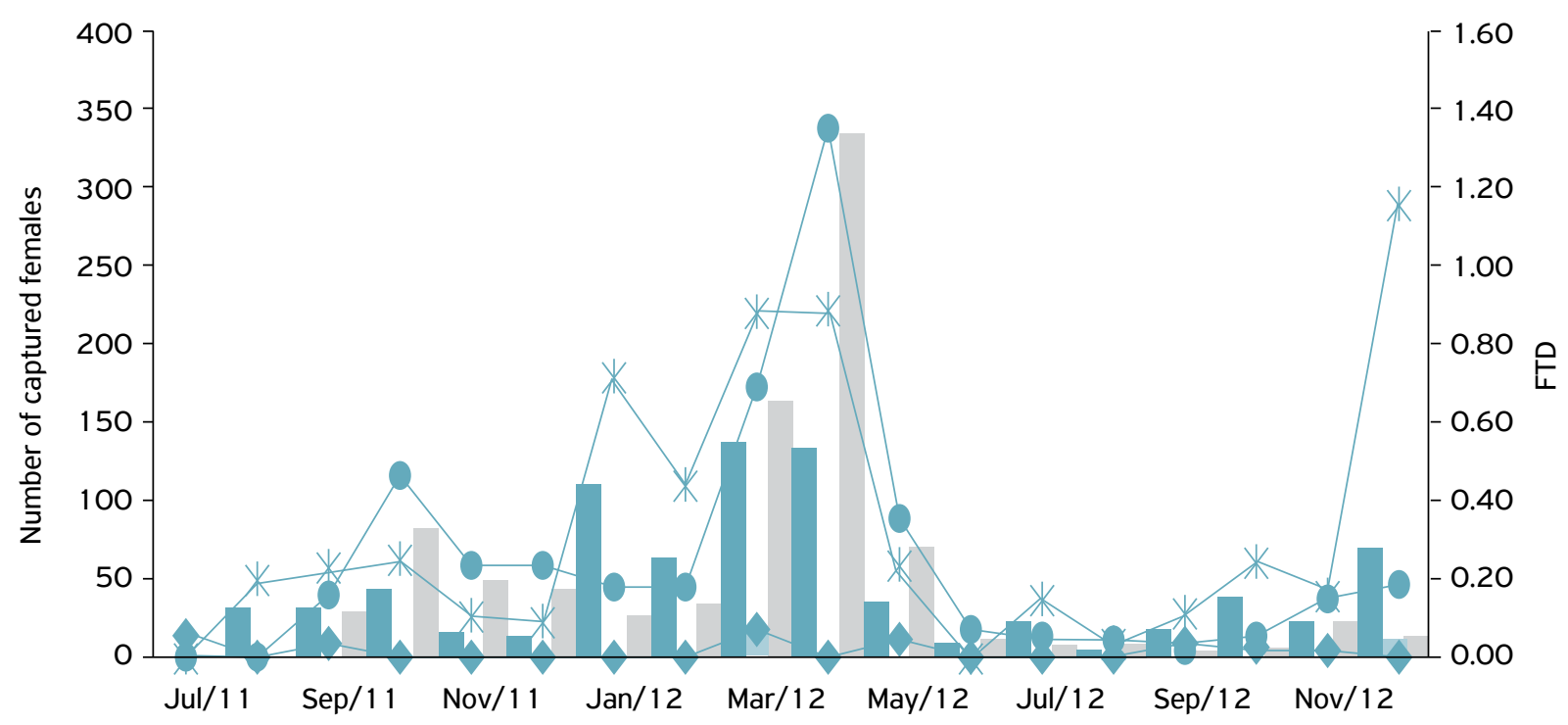

$\begin{array}{lll}\text { Ilhéus } & \text { Uruçuca } \\ - \text { Uruçuca } & * \text { Whenceslau Guimarães }\end{array}$

Figure 1. Total number of captured females and fly/trap/day (FTD) index of Anastrepha captured in McPhail traps in Ilhéus, Uruçuca and Wenceslau Guimarães, Bahia, July/2011 - December/2012.

From Lonchaeidae flies, only specimens of Neosilba were captured (38 females and 2 males). The species found were Neosilba glaberrima (Wied.) $(\mathrm{n}=1)$, in Wenceslau Guimarães, and $N$. zadolicha McAlpine \& Steyskal $(\mathrm{n}=1)$, in Uruçuca. The highest number of captures occurred in Wenceslau Guimarães $(\mathrm{n}=28)$, probably because the traps were placed in an orchard of Malpighia glabra L.

It is worth noting that there is no attractant developed to date to species of Neosilba. This may underestimate the populations of Neosilba species, as well as the number of species.

The presence of $N$. glaberrima was already recorded for Bahia (BitTenCourt et al., 2006b); this species infests different species of fruits (Lopes et al., 2008; Melo et al., 2012). Neosilba zadolicha was assigned as an important pest of citrus in the state of Mato Grosso do Sul (UchôA-Fernandes et al., 2003), and in the region of Recôncavo Baiano this species was recorded infesting fruits of umbu-cajá (Spondias tuberosa $\times S$. mombin) (SANTos et al., 2004).

Specimens of $C$. capitata were captured only in traps installed in the municipalities of Wenceslau Guimarães ( $n=7$ ) and Ilhéus $(\mathrm{n}=8)$. The location, diversity and quantity of native hosts in the areas where the traps were installed were probably the factors that contributed to the predominance of species of Anastrepha and low capture C. capitata index, similar to the results obtained by URAмото et al. (2004).

\section{CONCLUSION}

Anastrepha antunesi Lima, A. bahiensis Lima, A. consobrina (Loew), A. distincta Greene, A. fraterculus (Wied.), A. grandis (Macquart), A. leptozona Hendel, A. obliqua (Macquart), A. parallela (Wied.), A. serpentina (Wied.), A. sororcula Zucchi, A. zenildae Zucchi, Neosilba glaberrima (Wiedemann), and $N$. zadolicha McAlpine \& Steyskal are the species of frugivorous flies reported in the southern of Bahia. For the first time A. consobrina (Loew) is reported in the state of Bahia. In this region, the genus Anastrepha Schiner was predominant in relation to Ceratitis capitata (Wied.). Anastrepha fraterculus presented the highest population level in the region. The peaks of FTD recorded for Anastrepha species were coincident with the period of ripening fruits available to oviposition and so to the development of larvae and abundant food.

\section{ACKNOWLEDGEMENTS}

To the Universidade Estadual de Santa Cruz (UESC) and Fundação de Amparo à Pesquisa da Bahia (FAPESB), for grants; and to Coordenaçáo de Aperfeiçoamento de Pessoal de Nível Superior (CAPES), for the scholarship grant to the first author. 
AGUIAR-MENEZES, E.L; SOUZA, S.A.S.; LIMA-FILHO, M.; BARROS, H.C.; FERRARA, F.A.A.; MENEZES, E.E.B. Análise faunística de moscas-das-frutas (Diptera: Tephritidae) nas regiões norte e noroeste do estado do Rio de Janeiro. Neotropical Entomology, Londrina, v.37, n. 1, p.8-14, 2008.

ALUJA, M.; MANGAN R.L. Fruit fly (Diptera: Tephritidae) host status determination: critical conceptual, methodological, and regulatory considerations. Annual Review of Entomology, Palo Alto, v.53, p.473-502, 2008.

ARAÚJO, E.L.; RIBEIRO, J.C.; CHAGAS, M.C.M.; DUTRA, V.S.; SILVA, J.G. Moscas-das-frutas (Diptera: Tephritidae) em um pomar de goiabeira, no semiárido brasileiro. Revista Brasileira de Fruticultura, Jaboticabal, v.35, n.2, p.471-476, 2013.

AZEVEDO, F.R; GUIMARÃES, J.A.; SIMPLíCIO, A.A.F.; SANTOS, H.R. Análise faunística e flutuação populacional de moscas-dasfrutas (Diptera: Tephritidae) em pomares comerciais de goiaba na região do Cariri Cearense. Arquivos do Instituto Biológico, São Paulo, v.77, n.1, p.33-41, 2010.

BITTENCOURT, M.A.L.; COVA, A.K.W.; SILVA, A.C.M.; SILVA, V.E.S.; BOMFIM, Z.V.; SOUZA FILHO, M.F.; ARAÚJO, E.L. Espécies de moscas-das-frutas (Tephritidae) obtidas em armadilhas McPhail no estado da Bahia, Brasil. Semina: Ciências Agrárias, Londrina, v.27, n.4, p.561-564, 2006a.

BITTENCOURT, M.A.L.; SILVA, A.C.M.; SILVA, V.E.S.; BOMFIM, Z.V.; SOUZA FILHO, M.F.; ARAÚJO, E.L. Moscas-das-frutas (Diptera: Tephritidae) e seus parasitoides (Hymenoptera: Braconidae) associados às plantas hospedeiras no sul da Bahia. Neotropical Entomology, Londrina, v.40, n.3, p.405-406, 2011 . DOI: 10.1590/S1519-566X2011000300016

BITTENCOURT, M.A.L.; SILVA, A.C.M.; Z; BOMFIM, Z.V.; SILVA, V.E.S.; ARAÚJO, E.L.; STRIKIS, P.C. Novos registros de espécies de Neosilba (Diptera: Lonchaeidae) na Bahia. Neotropical Entomology, Londrina, v.35, n.2, p.282-283, 2006b.

DUTRA, V.S.; SANTOS, M.S.; SOUZA FILHO, Z.A.; ARAÚJO, E.L.; SILVA, J.G. Faunistic analysis of Anastrepha spp. (Diptera: Tephritidae) on a guava orchard under organic management in the municipality of Una, Bahia, Brasil. Neotropical Entomology, Londrina, v.38, n.1, p.133-138, 2009. DOI: 10.1590/ S1519-566X2009000100015

FEITOSA, S.S.; SILVA, P.R.R.; PÁDUA, L.E.M.; CARVALHO, E.M.S.; PAZ, J.K.S.; PAIVA, D.R. Flutuação populacional de moscas-dasfrutas (Diptera: Tephritidae) associadas a variedades de manga no município de José de Freitas - Piauí. Revista Brasileira de Fruticultura, Jaboticabal, v.30, n.1, p.112-117, 2008. DOI: 10.1590/SO100-29452008000100021

FERRARA, F.A.A.; AGUIAR-MENEZES, E.L.; URAMOTO, K.; MARCO JR., P.; SOUZA, S.A.S.; CASSINO, P.C.R. Análise faunística de moscas-das-frutas (Diptera: Tephritidae) da região noroeste do estado do Rio de Janeiro. Neotropical Entomology, Londrina, v.34, n.2, p.183-190, 2005.
LOPES, E.B.; BATISTA, J.L.; ALBUQUERQUE, I.C.; BRITO, C.H. Moscas frugívoras (Tephritidae e Lonchaeidae): ocorrência em pomares comerciais de tangerina (Citrus reticulata Blanco) do município de Matinhas, estado da Paraíba. Acta Scientiarum Agronomy, Maringá, v. 30, Suppl., p.639-644, 2008. DOI: 10.4025/actasciagron.v30i5.5964

MALAVASI, A.; ZUCCHI, R.A.; SUGAYAMA, R.L. Biogeografia. In: MALAVASI, A.; ZUCCHI, R.A. (Eds.). Moscas-das-frutas de importância econômica no Brasil: conhecimento básico e aplicado. Ribeirão Preto: Holos, 2000. chap.10. p.93-98.

MELO, E.A.S.; SANTOS, E.; ALMEIDA, F.R.; ROCHA, R.B.; SANTOS, O.O.; STRIKIS, P.C.; BITTENCOURT, M.A.L. Hospedeiros, níveis de infestação e parasitoides de moscas frugívoras (Diptera: Tephritidae e Lonchaeidae) em municípios da região sul da Bahia. Magistra, Cruz das Almas, v.24, n. especial, p.8-16, 2012.

MINZÃO, E.R.; UCHÔA-FERNANDES, M.A. Diversidade de moscas frugívoras (Diptera, Tephritoidea) em áreas de matas decídua e ciliar no pantanal sul-mato-grossense, Brasil. Revista Brasileira de Entomologia, v.52, n.3, p.441-445, 2008.

RONCHI-TELES, B.; SILVA, N.M. Flutuação populacional de espécies de Anastrepha Schiner (Diptera: Tephritidae) na região de Manaus, AM. Neotropical Entomology, Londrina, v.34, n.5, p.733-741, 2005. DOI: 10.1590/S1519-566X2005000500004

SÁ, R.F., CASTELLANI, M.A.; RIBEIRO, A.E.L.; PÉREZ-MALUF, R.; MOREIRA, A.A.; NAGAMOTO, N.S.; NASCIMENTO, A.S. Faunal analysis of the species Anastrepha in the fruit growing complex Gavião River, Bahia, Brazil. Bulletin of Insectology, v.65, n.1, p.37-42, 2012.

SANTOS, G.S.; PÁDUA, L.E.M. Flutuação populacional e espécies de moscas-das-frutas em citrus na cidade de Teresina-PI. Revista Caatinga, Mossoró, v. 17, n.2, p.87-92, 2004.

SANTOS, M.S.; NAVACK, K.I.; ARAÚJO, E.L.; SILVA, J.G. Análise faunística e flutuação populacional de moscas-das-frutas (Diptera: Tephritidae) em Belmonte, Bahia. Revista Caatinga, Mossoró, v.24, n.4, p.86-93, 2011.

SANTOS, O.O.; ANDRADE, L.L; BITTENCOURT, M.A.L. Moscasdas-frutas (Diptera: Tephritidae) em armadilhas tipo McPhail e frutos hospedeiros no município de Ilhéus, Bahia. Magistra, Cruz das Almas, v.20, n.4, p.398-402, 2008.

SANTOS, W.S.; CARVALHO, C.A.L.; MARQUES, O.M. Registro de Neosilba zadolicha McAlpine \& Steyskal (Diptera: Lonchaeidae) em umbu-cajá (Anacardiaceae). Neotropical Entomology, Londrina, v.33, n.5, p.653-654, 2004. DOI: 10.1590/ S1519-566X2004000500017

SILVEIRA NETO, S.; NAKANO, O.; BARBIN, D.; NOVA, N.A.V. Manual de ecologia dos insetos. Piracicaba: Ceres, 1976. $419 \mathrm{p}$.

STRIKIS, P.C.; PRADO, A.P. A new species of the genus Neosilba (Diptera: Lonchaeidae). Zootaxa, Auckland, v.828, p. 1-4, 2005. 
UCHÔA-FERNANDES, M.A.; MOLINA, R.M.S.; OLIVEIRA, I.; ZUCCHI, R.A.; CANAL, N.A.; DÍAZ, N.B. Larval endoparasitoids (Hymenoptera) of frugivorous flies (Diptera, Tephritoidea) reared from fruits of the cerrado of the state of Mato Grosso do Sul, Brazil. Revista Brasileira de Entomologia, v.47, n.2, p.181-186, 2003.

URAMOTO, K.; WALDER, J.M.M.; ZUCCHI, R.A. Biodiversidade de moscas-das-frutas do gênero Anastrepha (Diptera, Tephritidae) no campus da ESALQ-USP, Piracicaba, São Paulo. Revista Brasileira de Entomologia, Curitiba, v.48, n.3, p.409-414, 2004. DOI: 10.1590/S0085-56262004000300018

URAMOTO, K.; WALDER, J.M.M; ZUCCHI, R.A. Análise quantitativa e distribuição de populações de espécies de Anastrepha (Diptera, Tephritidae) no Campus Luiz de Queiroz, Piracicaba, SP. Neotropical Entomology, Londrina, v.34, n. 1, p.33-39, 2005.
ZUCCHI, R.A. Espécies de Anastrepha, sinonímias, plantas hospedeiras e parasitoides. In: MALAVASI, A.; ZUCCHI, R.A. Moscas-das-frutas de importância econômica no Brasil: conhecimento básico e aplicado. São Paulo: Holos, 2000 b. chap.4. p.41-48.

ZUCCHI, R.A. Taxonomia. In: MALAVASI, A.; ZUCCHI, R.A. Moscas-das-frutas de importância econômica no Brasil: conhecimento básico e aplicado. São Paulo: Holos, 2000a. chap.1. p.13-24.

ZUCCHI, R.A. Anastrepha species and their hosts plants. Fruit flies (Diptera, Tephritidae) in Brazil. Piracicaba: ESALQ/USP, 2008. Available from: <http://www.lea. esalq. usp.br/anstrepha/>edita_infos.htm>. Accessed on: 6 mar. 2014. 